\title{
"SOMOS RACISTAS?": \\ enfrentando o racismo institucional no Ministério Público de São Paulo
}

\section{Clio Nudel Radomysler}

\section{Palavras-Chave}

Ministério Público/racismo institucional/ branquitude/sistema de justiça

\section{SUMÁRIO}

\section{Introdução}

Metodologia: por que observar o cotidiano do sistema de justiça?

Discutindo igualdade em uma instituição desigual

O MP-SP diante do espelho: racismo institucional e branquitude em debate Retratos da desigualdade: o primeiro censo racial do MP-SP

Mapeando a (in)ação do MP-SP nos crimes de racismo e injúria racial

Acusar e defender: contradições do

Ministério Público

Conclusões

Referências

\section{Resumo}

O objetivo deste trabalho foi refletir sobre o papel das instituições do sistema de justiça no enfrentamento ao racismo. Foi realizada uma etnografia do Grupo de Trabalho da Igualdade Racial Professor Joel Rufino dos Santos do Ministério Público de São Paulo, grupo criado especificamente para tratar do assunto no âmbito do MP-SP, entre setembro de 2014 e março de 2016.

O GT-Igualdade Racial priorizou capacitar seus integrantes para identificar a reprodução do racismo no funcionamento cotidiano da própria instituição. O Grupo também buscou sensibilizar seus participantes a perceberem seu papel individual na manutenção do racismo.

Além de estratégias de capacitação, a partir dessa pesquisa foi possível elencar importantes medidas de combate ao racismo nas instituições do sistema de justiça: a implementação de cotas raciais; a coleta, a análise e divulgação de dados sobre casos relacionados à população negra; e o estabelecimento de diretrizes institucionais e órgãos especializados no tema.

Este trabalho também identificou inúmeras dificuldades enfrentadas pelo Grupo, como a grande rejeição dos promotores e procuradores às cotas raciais, a estrutura institucional hierárquica, a ausência de canais de diálogo com movimentos sociais, a excessiva valorização da independência funcional, e as contradições decorrentes do desenho institucional do MP, com atribuições ao mesmo tempo de acusação penal e promoção de direitos.

Apesar dos avanços conseguidos pela atuação do GT-IR, ainda resta um longo caminho a ser percorrido para combater as diversas manifestações do racismo dentro do sistema de justiça.

p Mestranda em Direito do Estado (subárea Direito Constitucional) pela Faculdade de Direito da Universidade de São Paulo (FDUSP), onde também se graduou em Direito. Integrante do Centro de Ensino e Pesquisa em Inovação (CEPI) da FGV DIREITO SP, colaboradora da Escola de Formação da Sociedade Brasileira de Direito Público (SBDP) e coordenadora do Núcleo de Direito Discriminação e Diversidade (DDD) da Faculdade de Direito da USP. 


\title{
"ARE WE RACISTS?" \\ Facing institutional racism in the Public Prosecutor's Office of São Paulo
}

\author{
Clio Nudel Radomysler
}

\section{Key words}

Public Prosecutor's Office/institutional racism/whiteness/justice system

\begin{abstract}
The purpose of this work was to reflect on the role of the justice system's institutions in confronting racism. We conducted an ethnography of the Racial Equality Working Group Professor Joel Rufino dos Santos of the Public Prosecutor's Office of São Paulo, a group created to deal with the subject within the MP-SP, between September 2014 and March 2016.
\end{abstract}

The Racial Equality Working Group prioritized the training of its members to identify the reproduction of racism on the daily activities of the institution. The Group also sought to raise the participants' awareness about their own role on the perpetuation of racism.

In addition to training programs, this research discussed important measures to fight racism in the justice system's institutions: the implementation of racial quotas; the collection, analysis and dissemination of data regarding cases related to the black population; and the establishment of institutional guidelines and specific departments to address this theme.

This work also identified numerous difficulties faced by the Group: the strong rejection to the adoption of racial quotas by the prosecutors, the hierarchical institutional structure, the lack of dialogue with social movements, the excessive valorization of the prosecutor's functional independence, and the inherent contradictions of the MP's institutional design - the MP acts at the same time on criminal prosecution and on the promotion of civil rights.

Despite the progress made by the Group, there is still a long way to go in order to confront the various manifestations of racism within the justice system. 


\section{INTRODUÇÃO}

Reunimos colegas, promotores e servidores do Ministério Público interessados em discutir a questão racial. Não apenas no que se refere ao Ministério Público processando autores de racismo ou entrando com ações civis públicas em face das questões raciais, mas sobretudo em face do nosso racismo institucional, interno. Nós somos ainda uma instituição cujos membros negros contamos em duas mãos.

(Promotor Coordenador do Grupo de TrabaIho da Igualdade Racial Professor Joel Rufino dos Santos do Ministério Público do Estado de São Paulo, $1^{a}$ Reunião de Formação, 9 de março de 2015)

Definir e aplicar o conceito de racismo institucional, identificar a reprodução do racismo nas práticas internas do Ministério Público do Estado de São Paulo (MP-SP), e discutir a ausência de negros na instituição são elementos presentes em todas as reuniões do Grupo de Trabalho da Igualdade Racial Professor Joel Rufino dos Santos² (GT-Igualdade Racial).

Este grupo foi criado pelo Núcleo de Políticas Públicas do MP-SP, órgão de assessoria da Procuradoria Geral de Justiça (PGJ), para articular políticas institucionais que aprimorassem a atuação do MP no enfrentamento ao racismo. As atividades do GT-Igualdade Racial desenvolveram-se entre setembro de 2014 e março de 2016, reunindo 43 membros do MP-SP, servidores e promotores da instituição. ${ }^{3}$

\footnotetext{
Em outubro de 2015, o GT-Igualdade Racial do MP-SP decidiu mu dar o seu nome para prestar uma homenagem ao Professor Joel Rufino dos Santos, historiador, professor e escritor brasileiro, especialista em cultura e herança africanas no Brasil, que faleceu em 2015.

Nos documentos produzidos pelo GT-Igualdade Racial, o termo "membros" do MP se referia apenas aos promotores e procuradores. Os funcionários são nomeados como "servidores". Neste trabalho, uti lizarei o termo membros para me referir a todos os integrantes da instituição.
}

Conforme seu coordenador, o GT-IR surgiu da pressão de organizações da sociedade civil, e do próprio poder público, que nas últimas décadas vem instigando o Ministério Público a enfrentar a temática da igualdade racial, dando mais ênfase para as demandas sociais e para a promoção de direitos.

Já na primeira reunião ordinária, em 23 de outubro de 2014, um promotor observou: "A população da periferia não confia no Ministério Público, vendo-o como uma instituição racista, conservadora e intolerante. A instituição deve fazer autocrítica sobre o seu trabalho e iniciar um processo de desconstrução do racismo interno".

Na Constituição de 1988 (CF/1988) houve uma ampla redefinição do perfil do Ministério Público como ator político no cenário nacional (Sadek, 1997). O MP adquire a responsabilidade de defender a ordem jurídica, o regime democrático e os interesses sociais e individuais indisponíveis (art. 127, CF/1988). A instituição passa a exercer, além da sua tradicional função de acusação penal, a defesa dos direitos difusos e coletivos e o controle externo da atividade policial (art. 129, CF/1988). A Constituição assegurou ainda a autonomia administrativa do MP em relação aos poderes Executivo, Legislativo e Judiciário, bem como a independência funcional dos seus membros (art. $127, \S 1^{\circ}$ e $\S 2^{\circ}$ ).

Neste contexto, destaca-se entre os objetivos do MP a promoção da igualdade racial, fundamental para a defesa dos interesses sociais e valores democráticos. Além de promover a ação penal nos casos dos crimes de racismo e injúria racial, o MP conta com o Inquérito Civil Público e a Ação Civil Pública, instrumentos jurídicos para a proteção dos direitos difusos e coletivos, que podem ser utilizados para combater violações de 
direitos da população negra brasileira em diversas áreas, como educação, saúde, consumidor, patrimônio histórico, atividades policiais e prisões.

Surgem então muitas questões. Como o Ministério Público desempenha a sua atribuição de defesa dos direitos da população negra brasileira? De que forma os seus membros percebem a assim chamada "questão racial no Brasil"? Que papel a instituição deve assumir na luta antirracista? Quais são os principais desafios para que o MP seja um ator relevante para o enfrentamento ao racismo?

O presente artigo busca relatar e analisar a atuação e o posicionamento do GT-Igualdade Racial do MP-SP em relação a essas questões, por meio de um estudo etnográfico do Grupo. O objetivo foi procurar compreender como o maior Ministério Público Estadual do País vem assumindo sua função constitucional de defesa dos interesses sociais, e contribuir para a reflexão sobre as possibilidades e limites das instituições do sistema de justiça no enfrentamento ao racismo.

Para o Grupo, a falta de conhecimento dos promotores e procuradores sobre questões raciais e a ausência de negros no MP-SP dificultam uma atuação eficiente da instituição para a promoção da igualdade racial. Para dar conta destes desafios, as principais realizações do GT-IR foram: a sensibilização dos integrantes do GT sobre o tema, com reuniões de formação sobre racismo institucional e branquitude; e a busca pela aprovação de cotas raciais nos concursos da instituição, por meio da realização do primeiro censo racial do MP-SP. O GT-Igualdade Racial procurou também combater a forte hierarquia entre promotores, procuradores e demais funcionários da instituição, constituindo-se como o primeiro grupo do MP-SP aberto para a participação ativa dos servidores interessados.

Resultados da pesquisa indicam inúmeras dificuldades enfrentadas pelo Grupo, que não conseguiu combater a grande rejeição da maior parte dos membros da instituição contra as cotas raciais e nem avançar em discussões sobre violência policial e o encarceramento da população negra. O GT também não foi capaz de estabelecer diretrizes para a atuação da instituição na persecução penal dos crimes de racismo e injúria racial, e não houve qualquer aproximação com movimentos sociais.

Neste artigo analisaremos essas e outras práticas realizadas pelo GT-Igualdade Racial Professor Joel Rufino dos Santos. Veremos que, apesar de grandes limitações, a atuação do GT-Igualdade Racial pode inspirar importantes transformações nas instituições do sistema de justiça, que são urgentes e necessárias.

\section{METODOLOGIA: POR QUE OBSERVAR O COTIDIANO DO SISTEMA DE JUSTIÇA?}

Para refletir sobre o papel do Ministério Público no enfrentamento ao racismo, foi fundamental, ao menos no caso desta pesquisa, a escolha da etnografia e de uma abordagem interdisciplinar como eixos teórico-metodológicos.

A etnografia usa a lógica de contextos particulares como meio de iluminar as complexas inter-relações entre os elementos políticos, legais, históricos, sociais, econômicos e culturais (Scheppele, 2004, p. 390). Permite uma maior proximidade com o contexto pesquisado e a vivência do fenômeno observado no próprio lugar de seu acontecimento, familiarizando-se com a linguagem 
utilizada, com os significados compartilhados, atitudes, interesses e comportamentos (Proença, 2008).

A etnografia possibilitou a compreensão de questões relevantes sobre a recente função constitucional do Ministério Público na defesa de interesses sociais que não poderiam ser observadas de outras formas. Estas questões envolvem vantagens e desvantagens das estruturas organizacionais e dos instrumentos jurídicos utilizados pelo MP, a relação da instituição com os movimentos sociais e a sociedade civil, bem como a formação dos profissionais do direito no tema do racismo. A etnografia também permitiu entender como os próprios representantes dessas instituições veem seu papel na defesa da população negra brasileira.

Conforme Luiz Eduardo Abreu, não se trata de menosprezar a importância da análise dogmática ou jurisprudencial, mas de realizar uma reflexão do direito em sua prática cotidiana, usando métodos capazes de reconstituir os detalhes vivos do cenário político-legal, que, usualmente, não encontram muito espaço na discussão doutrinária (Abreu, 2013, p. 17).

Além disso, é importante não perder de vista a complexidade que envolve os processos de construção da identidade negra em nosso país, e os diferentes usos sociais do conceito de raça. Apenas por meio de um material bibliográfico interdisciplinar foi possível abordar os discursos sobre as relações raciais no Brasil e refletir sobre o por vezes contraditório entrelaçamento de instituições, indivíduos, estruturas organizacionais, normas, valores e sensibilidades no cotidiano das práticas do sistema de justiça.

Para realizar uma etnografia do GT-Igualdade Racial Professor Joel Rufino dos Santos foram utilizadas e combinadas as seguintes técnicas de pesquisa: 1) observação das reuniões do Grupo; 2) entrevistas semiestruturadas com seus integrantes; e 3) análise de documentos produzidos pelo $\mathrm{GT}^{4}$.

A inserção do pesquisador no campo nunca é simples, principalmente quando se trata de uma etnografia, pois o pesquisador se torna de alguma forma parte do universo investigado (Jaccoud, 2012). No caso da presente pesquisa, a inserção no campo parecia ser um grande desafio. Em primeiro lugar, estudos indicam a falta de abertura das instituições do sistema de justiça para o trabalho de campo, e não encontrei outras pesquisas que tivessem realizado uma etnografia no Ministério Público.

Em segundo, no meu imaginário, por ser uma mulher jovem, estudando questões de direitos humanos, seria tratada com suspeita pelos membros do MP. Em minhas redes de sociabilidade, o Ministério Público, em geral, é considerado uma instituição tradicional e conservadora, majoritariamente masculina, e mais preocupada com a acusação penal do que com a promoção de direitos difusos e coletivos. Por outro lado, características da minha identidade social, semelhantes às dos promotores e procuradores do MP-SP, poderiam facilitar a minha inserção no campo: sou branca, de classe social alta e formada na Faculdade de Direito da USP. Além disso, na proposta de trabaIho do GT-Igualdade Racial, havia indicação para que o Grupo se aproximasse de universidades e instituições de pesquisa.

Para realizar o primeiro contato com a instituição enviei um e-mail ao coordenador

${ }^{4}$ O GT-Igualdade Racial produziu inúmeros documentos ao longo dos seus trabalhos: Memórias das 9 (nove) reuniões ordinárias; Vídeos das 4 (quatro) reuniões de formação; 6 (seis) Boletins Informativos; 3 (três) Boletins de Diálogos Culturais; Relatório sobre o censo racial; Levantamento de dados sobre os crimes de racismo e injúria racial; dentre tamento de dados sobre os crimes de racismo e injú 
do GT-Igualdade Racial, integrante do Núcleo de Políticas Públicas do MP-SP. Após uma reunião com ele e uma promotora do Núcleo de Políticas Públicas, também responsável pela direção do Grupo, enviei uma solicitação aos membros do GT-Igualdade Racial para acompanhar suas reuniões, que foi aprovada por todos. Na primeira reunião ordinária de que participei, em fevereiro de 2015, fui incluída nos grupos de WhatsApp e de e-mails, o que mostrou abertura para a pesquisa.

O momento da realização das entrevistas ocorreu após um período inicial de acompanhamento das reuniões do Grupo. Foram realizadas 18 entrevistas semi-esturutradas; para resguardar a identidade dos entrevistados, escolhi não mencionar seus nomes, mesmo tendo recebido autorização da maioria deles. ${ }^{5}$

Segundo Laura Beth Nielsen, como o próprio fenômeno do direito é constituído por indivíduos, configurações organizacionais, instituições sociais e as interações entre eles, a plena compreensão do direito exige pesquisas conduzidas usando abordagens múltiplas (Nielsen, 2010, p.972). Para alcançar os objetivos do estudo procurei, portanto, articular a base teórica adotada e os diferentes dados empíricos coletados por meio da observação das reuniões, das entrevistas e da análise dos documentos produzidos pelo Grupo. Espero que o resultado deste esforço consiga expressar a multiplicidade e potencialidade do material coletado e das experiências vivenciadas em campo.

\footnotetext{
Por limitações de tempo, não poderia entrevistar todos os 43 integrantes do Grupo. Utilizei dois critérios para selecionar os entrevistados: (a) ter participado de 3 ou mais reuniões ordinárias, ou seja, mais da metade das reuniões realizadas; ou (b) ter realizado individualmente estratégias importantes de combate ao racismo no MP-SP. O roteiro da entrevista abordou os seguintes temas: (a) interesse no tema e participação no Grupo; (b) possibilidades e limites das estratégias do GT-IR; e (c) o papel do MP-SP no enfrentamento ao racismo.
}

\section{DISCUTINDO IGUALDADE EM UMA INSTITUIÇÃO DESIGUAL}

Temos uma cultura de divisão no Ministério Público: promotores, procuradores e os outros. Como se a gente não integrasse a mesma instituição. Isso ocorre em vários campos. Esse GT, ao integrar promotores e servidores, parece dar um passo muito pequenininho. De fora parece algo muito banal, mas isso é um grande avanço.

Esta declaração, feita por um promotor entrevistado, demonstra a importância do GT-Igualdade Racial como o primeiro grupo a contar com a participação ativa de servidores do MP. Conforme os participantes do Grupo, há uma forte hierarquia nas instituições do sistema de justiça, que diferencia os membros concursados, que realizam as atividades jurídicas principais, dos demais funcionários. Convidar os servidores interessados, fazer as reuniões em formato de roda, e incentivar a contribuição de todos foram práticas inovadoras dentro do contexto do MP-SP e do sistema de justiça.

O coordenador contou que a inspiração para essa medida foi o GT-Racismo do MP de Pernambuco. Em entrevista, ele relatou:

O fundamental para que o GT produza o que tem produzido é o fato de termos aberto a participação para todos os funcionários. Foi o que deu o caráter democrático, plural, mais participativo e menos elitista. Acho que foi uma sacada muito importante, uma conquista de gol de placa (...). Uma instituição que tem o papel de defender a democracia, e não ser democrática, é uma contradição insuportável.

A presença dos servidores também foi essencial para que pessoas negras participassem do GT-IR. Ao todo, foram 43 os integran- 
tes do GT: 22 servidores, dentre os quais 10 pessoas negras, todas mulheres; e 21 promotores, todos brancos. Servidoras negras do Grupo afirmaram que trabalham no MP há mais de 20 anos e essa foi a primeira vez que observaram e participaram de um debate sobre racismo na instituição.

Essa estratégia também foi importante porque os servidores tiveram participação mais constante do que os promotores. As reuniões contaram com uma média de 20 membros: 13 servidores e 7 promotores. Apenas três promotores participaram de três ou mais reuniões ordinárias, ao passo que, entre os servidores, foram nove os que estiveram presentes em mais de três reuniões.

Outra importante medida realizada pelo GT-Igualdade Racial foi exigir a participação de promotores em "cargos-chave" da instituição, os promotores de justiça dos Centros de Apoio Operacional às Promotorias de Justiça Cível e de Tutela Coletiva (CAO Direitos Humanos), e Criminal (CAO Crim), e os promotores assessores da Escola Superior do MP-SP. O promotor indicado pelo CAO Crim, em entrevista, mencionou a importância dessa estratégia:

O Núcleo de Políticas Públicas fez questão de ter o CAO Crim e o CAO Direitos Humanos no Grupo, além de abrir para quem tivesse interesse, porque são cargos-chave no MP. Aqui a gente tem muito contato com o promotor criminal, é um órgão que realmente está todo dia falando com o estado inteiro. Então, com essa capacitação do GT, a gente vai conseguir espalhar um pouco do que aprendeu. Nem todo mundo vai ser de pronto receptivo a alterações, mas com o tempo a gente vai avançar.

Quanto aos servidores, não havia uma previ- são de cargos específicos para compor o Grupo. Conforme uma servidora entrevistada:

Os voluntários do Grupo, aqueles que não têm uma função especificada, são os negros. São servidores que estão no MP e que vem de uma luta cansada; que olham para o GT e pensam: será que é verdade?

As reuniões contaram com promotores e servidores de diferentes setores do MP-SP, por exemplo, área do idoso, criminal, violência doméstica e saúde pública; e com diferentes formações e funções: jurídica, administrativa, comunicação, audiovisual, socioassistencial, entre outras, o que contribuiu para os debates e para a formulação das estratégias de atuação do Grupo.

Uma limitação importante, contudo, foi a participação de apenas uma integrante do MP de fora da Capital. Conforme a servidora, "eu me inscrevi porque eu estou no interior e aqui, onde são formados os grupos, é o centro das decisões do Ministério Público de São Paulo". A falta de assiduidade dos promotores e os poucos promotores voluntários também limitaram o alcance do trabalho do GT. Vale mencionar a inexistência de discussão sobre a participação de funcionários terceirizados do MP-SP no Grupo. Não houve também qualquer menção sobre a ausência de procuradores no GT-IR.

A grande maioria dos entrevistados afirmou que não havia hierarquias ou desigualdades entre os participantes do GT. Conforme a fala de um servidor em entrevista:

No GT, acho que todos participam com igualdade. Lá eles cumprimentam, procuram chamar todo mundo pelo nome, há uma troca. O coordenador é muito atencioso, faz questão que todos tenham voz. Os promotores que vão lá também 
são muito bacanas. Eu fico pensando se eu vejo alguma hierarquia, mas acho que não, eu não senti. Eu acho que todo mundo fala sua opinião e escuta o outro. Acho que deve ser o primeiro grupo do MP assim, com mais democracia.

Foi possível identificar ponderações sobre a igualdade de participação, decorrentes da forte estrutura hierárquica da instituição e da pouca voz dada aos servidores em sua direção. Em uma entrevista realizada com duas servidoras, uma delas afirmou:

Nós estamos falando no GT em compreender que pessoas brancas têm privilégios e que é preciso combater esses privilégios. Mas a própria instituição não quer e não vai abrir mão dos seus privilégios. Eu estou falando da porta de entrada, que tem uma porta para os promotores e uma porta para os outros (...) dos banheiros exclusivos para promotores, que só eles têm a chave (...) do quadro pregado na cozinha geral falando que as xicaras são só para uso dos promotores (...) da própria ata do GT, que antes do nome dos promotores está escrito Doutor, já diferenciando e colocando você no seu lugar (...) As pessoas não estão dispostas a se desfazer dos privilégios e nem a socializá-los. Tem até um promotor que disse para a gente uma vez, em tom de brincadeira: Desculpa estar vestido dessa forma, mas preciso estar assim para me diferenciar de vocês. Então é contraditório nesse sentido.

Podemos concluir que, apesar da força das relações hierárquicas da instituição e da dificuldade de engajamento constante dos promotores, O GT-IR conseguiu promover a participação de promotores e servidores, com horizontalidade, na discussão aberta de temas sensíveis, que não eram abordados institucionalmente.

\section{O MP-SP DIANTE DO ESPELHO: RACISMO INSTITUCIONAL E BRANQUITUDE EM DEBATE}

Buscamos alternativas para enfrentar o nosso racismo, que trazemos aqui dentro. Muitas vezes nem o identificamos claramente, somos racistas sem perceber. (...) É preciso que nós nos perguntemos: você é racista? Que nós usemos algum tipo de estratégia para que nós efetivamente olhemos no espelho e consigamos identificar nosso racismo.

Ao fazer esta declaração, na primeira reunião de capacitação do GT-Igualdade Racial, o promotor coordenador ilustra um dos principais objetivos do Grupo: despertar os integrantes do MP-SP para o racismo na própria instituição e sensibilizar os participantes a empreender uma desconstrução pessoal diária contra o racismo.

Para atingir esses objetivos, o GT-Igualdade Racial discutiu e colocou em prática diferentes iniciativas. A principal delas foi a realização de quatro reuniões de formação com diferentes palestrantes convidados. ${ }^{6}$ Conforme o coordenador, na abertura de uma reunião de formação:

A cada 60 dias, intercalando com as reuniões de trabalho, nós fazemos essas chamadas "reuniões de formação", em que trazemos, para nossa alegria, profissionais, pesquisadoras, estudiosos do assunto, de fora do MP, para nos falarem sobre o racismo e nos

Os temas e os convidados das reuniões de formação foram: Silvio de Almeida, Doutor em Filosofia e Teoria Geral do Direito pela Universidade de São Paulo (USP), sobre Racismo Institucional e Atuação do Ministério Público (março/15); Lia Vainer Schucman, Professora, Doutora em Psicologia Social pela USP, sobre O lugar do branco nas relações raciais brasileiras (maio/15); Sérgio Adorno, Professor Titular em Sociologia da FFCLH e integrante do Núcleo de Estudos da Violência da Universidade de São Paulo (USP), sobre Discriminação Racial e Justiça Penal (agosto/15); e Alysson Mascaro, Livre-docente de Teoria Geral do Direito e Professor Titular de Filosofia da Universidade de São Paulo, sobre Igualdade e Democracia na perspectiva do racismo no Brasil (outubro/15). 
dotarem de conhecimentos a respeito do assunto. Não apenas de conhecimentos no campo da racionalidade, mas também da sensibilidade, porque esse assunto não se resolve apenas no âmbito da razão. $O$ racismo nos entranha a alma. Como nós sabemos, muitas vezes somos traídos pela nossa própria formação, nossa visão racista de mundo.

A percepção de que o racismo no Brasil "entranha a alma" e de que "somos racistas sem perceber" é constante entre os integrantes do GT. Por isso, entendem que, para provocar mudanças de comportamento da instituição com relação ao racismo, é fundamental ir muito além da difusão de informação sobre o tema.

Uma medida fundamental para atingir esse objetivo foi priorizar, na escolha dos temas e dos convidados das reuniões de formação, discussões sobre o racismo institucional no MP-SP e no sistema de justiça como um todo.

O conceito do racismo institucional foi utilizado de forma pioneira, em 1967, por ativistas do grupo Panteras Negras, para especificar como se manifesta o racismo nas estruturas de organização da sociedade (Geledés, 2013b, p.11). No Brasil o conceito passou a ser apropriado, a partir da década de 1990, por movimentos sociais negros e seu emprego na formulação e execução de programas federais começou apenas em 2005, com o Programa de Combate ao Racismo Institucional (IPEA, 2007).

Este Programa de Combate definiu o racismo institucional como "o fracasso das instituições e organizações em prover um serviço profissional e adequado às pessoas em virtude de sua cor, cultura, origem racial ou étnica. Ele se manifesta em normas, prá- ticas e comportamentos discriminatórios adotados no cotidiano do trabalho, os quais são resultantes do preconceito racial, uma atitude que combina estereótipos racistas, falta de atenção e ignorância" (Geledés, 2013a, p.11).

O foco das discussões no racismo institucional permitiu, em primeiro lugar, uma compreensão mais ampla sobre a produção e reprodução das desigualdades raciais brasileiras, que faz parte do próprio modo com que historicamente se estruturam as relações sociais no Brasil. Para o GT, o racismo está presente de forma estrutural na sociedade brasileira e, portanto, é um elemento constituinte das instituições, como o Ministério Público. Logo no início da primeira reunião de formação, Silvio de Almeida, Doutor em Filosofia do Direito pela Universidade de São Paulo (USP), afirmou:

Acho que esse é o ponto central que nós temos que tratar aqui. Nós temos que, primeira coisa, desmentir o seguinte: nós vivemos em uma sociedade racista. Ela não está racista, não é eventualmente racista. A sociedade que nós vivemos é constituída pelo racismo. Esse é o ponto de partida da nossa reflexão, e não só da nossa reflexão, mas também de um planejamento de uma ação de combate ao racismo institucional.

O termo racismo institucional também permitiu a reflexão sobre o papel do racismo como marco legitimador e definidor de prioridades de atuação do Ministério Público. O professor Silvio de Almeida, por exemplo, enfatizou que a reprodução do racismo se dá principalmente pela omissão, como no caso dos Ministérios Públicos não reagirem contra o número alarmante de homicídios que atingem a juventude negra. O professor 
também indicou que os MP's não fiscalizam a implementação da Lei 10639, de 2003, que inclui no currículo oficial das escolas a obrigatoriedade do ensino da história e cultura afro-brasileiras.

Um promotor do GT, por sua vez, em uma reunião de formação, apontou para a relação entre a reprodução das estruturas de exclusão racial e o enfoque do MP-SP para a atuação criminal:

A atividade criminal continua sendo o carro chefe do MP. Até que ponto não reproduzimos estruturas racistas perversas e investimos na exclusão dos negros, à medida que mais e mais os colocamos no sistema prisional. Sabemos que a entrada no sistema prisional é caminho sem volta.

Estudar o conceito de racismo institucional possibilitou também que os participantes do GT constatassem a naturalização do racismo na cultura institucional do MP-SP. Os integrantes do Grupo observaram como o racismo passa a fazer parte da ordem "natural" das coisas, independentemente da expressa vontade das pessoas e de atos explícitos ou declarados de discriminação racial. Um promotor, por exemplo, comentou em entrevista:

A minha experiência como promotor criminal mostrou que não é necessariamente aquela coisa de é negro então vamos condenar. É algo que vai automaticamente, na base dos estereótipos e não no nível da consciência. É um negócio que fica já no natural porque está interiorizado. Eu mencionei na palestra do Prof. Sergio Adorno esse caso porque até hoje não esqueço. Um juiz, bom menino, filho de desembargador, disse para mim: soltei um réu de roubo porque não tinha cara de assaltante, era loiro de olhos verdes.
Não é que a pessoa faz com maldade, é racista no sentido da maldade. Está tão naturalizado que sai naturalmente.

Uma importante crítica ao conceito de racismo institucional é que ele faz do racismo um fenômeno a repousar aparentemente sobre mecanismos abstratos - como a estrutura da sociedade e a cultura das instituições - e sem atores identificáveis (Santos, 2013, p.26). O GT-Igualdade Racial, entretanto, buscou combater o comportamento individual de desresponsabilização pela manutenção do racismo. A principal medida para atingir esse objetivo foi promover reflexões sobre branquitude nas reuniões de formação.

Os estudos críticos da branquitude emergiram nos Estados Unidos na década de 90, e no Brasil somente a partir do ano 2000. A branquitude é entendida como uma posição em que sujeitos classificados socialmente como brancos são sistematicamente privilegiados no acesso a recursos materiais e simbólicos (Shucman, 2012).

Um dos efeitos da branquitude é o indivíduo branco não pensar sobre si mesmo como um ser que possui uma identidade racial que gera privilégios. Além disso, por não sofrer os efeitos do racismo, as pessoas brancas muitas vezes naturalizam ou minimizam os efeitos do racismo na sociedade brasileira, e não são capazes de traduzir e interpretar os códigos e práticas racializadas de nossa sociedade (Shucman, 2012). As reuniões de formação contribuíram para que os membros do Grupo percebessem essa dinâmica, conforme relata um promotor entrevistado:

A gente vai evoluindo nas palestras de capacitação. Veja, eu que sou branco, nunca vivi nenhum tipo de preconceito por ser branco. Então a gente não sabe o que é, 
mas quando a gente ouve, a gente muda um pouco a visão. O Prof. Silvio mesmo disse: se eu estou no elevador e uma pessoa não me cumprimenta, eu nunca vou pensar que é porque sou branco, mas o negro pensa isso. Ele pensa porque toda hora ele passa por isso. São coisas que a gente sabe que existem, mas quando a gente vê pessoas mais próximas falando e contando experiências, vê que o problema é muito maior.

O foco no conceito de branquitude também contribuiu para que os integrantes do GT assumissem a responsabilidade pela manutenção do racismo na instituição. Uma característica do racismo no Brasil, já descrita por Florestan Fernandes em 1960, é a dificuldade de nos reconhecermos racistas. A crença na democracia racial e nos valores antirracistas, historicamente reproduzida na sociedade brasileira, produz um senso de alívio entre os brancos. Tanto os palestrantes quanto os integrantes do GT buscaram combater esse comportamento individual de negação do próprio racismo. Na primeira reunião de formação, Silvio de Almeida afirmou:

O MP é perpassado pela ideologia do racismo, portanto ele também é racista e as pessoas que estão nesse espaço de interação também serão racistas. Ah!, mas eu não sou racista! Desculpa, como não? Você vive em uma instituição, trabalha aqui, você gosta, tem orgulho de ser promotor em uma instituição que não tem negros, que denuncia pessoas negras, e que põe pessoas negras na cadeia o tempo todo. E acha isso normal. Como você não é racista? Você é sim. Você não quer ser, isso é outra história. Aí vamos dar o primeiro passo. Temos então que partir para processos de desconstrução, de desaprender a ser racista.
Além disso, o conceito de branquitude possibilitou o reconhecimento da necessidade de um engajamento ativo das pessoas brancas na luta antirracista e provocou mudanças de comportamento entre os integrantes do GT. Segundo o comentário de um promotor do Grupo em uma reunião de formação:

Nunca fui vítima de discriminação e me declaro branco. Eu sempre me opus ao racismo de forma distante, quase teórica. Como promotor, eu tinha um incômodo profundo com o racismo, sou adepto da democracia. Eu tinha desconforto político com a desigualdade racial, mas sempre distante. Quando me aproximei do tema da branquitude entendi que não era um mero espectador, mas estava dentro de um problema enorme. Como a palestra da Lia Shucman mostrou, não é uma questão que diz respeito aos outros. Sou parte disso independentemente da minha situação profissional e preciso achar um caminho para enfrentar essa realidade. Não posso me confortar na mesma posição, não sou apenas espectador.

Por fim, um importante objetivo das reuniões de capacitação é "misturar conteúdo com emoção". Para isso, o GT buscou trazer manifestações culturais para as formações: realizou, junto com a Escola Superior do MP-SP, um cine-debate sobre o documentário "Olhos Azuis" com a participação da psicóloga Maria Lúcia da Silva, do instituto AMMA - Psique e Negritude, e a última reunião contou com uma apresentação artística de Jovens da Fábrica de Cultura da Vila Nova Cachoeirinha.

Além das reuniões de capacitação, o GT-Igualdade Racial realizou outras estratégias de qualificação sobre o tema da igualdade 
racial, voltadas tanto aos seus próprios integrantes quanto aos demais membros da instituição.

As medidas direcionadas a seus integrantes foram a elaboração de um boletim com sugestões culturais, chamado Diálogo Cultural, e a criação de um grupo no WhatsApp ${ }^{7}$. As trocas de sugestões de filmes, livros e eventos contribuíram para a sensibilização dos integrantes do GT. No mesmo sentido, - WhatsApp permitiu uma comunicação mais informal e espontânea entre os membros do Grupo, possibilitando que continuassem se envolvendo com seus objetivos fora do espaço institucional.

Para o Ministério Público, o Grupo Trabalho elaborou seis Boletins Informativos que foram distribuídos por via eletrônica a todos seus integrantes. A edição do Boletim Informativo, que contou com textos escritos por promotores e servidores do GT, teve por objetivo provocar a reflexão dos membros do MP-SP sobre a profundidade do problema do racismo no país e sobre a importância da implementação das cotas raciais. Os Boletins também divulgaram o trabalho do Grupo e a possibilidade dos interessados ingressarem a qualquer tempo no GT.

O Grupo também enviou um ofício para o diretor da Escola Superior do Ministério Público solicitando a inclusão dos temas gênero e igualdade racial no módulo inicial de formação dos promotores de justiça; e a introdução, na formação que ocorre ao longo dos dois anos de início de carreira dos promotores, de outros temas ligados às pessoas em situação de vulnerabilidade, tais como população LGBT e população em situação de rua.

\footnotetext{
Inicialmente, foi discutida a possibilidade de enviar o boletim Diálogos Culturais para todos os integrantes do MP-SP mas concluiu-se que essa iniciativa poderia causar mais rejeição com relação ao tema do que sensibilização.
}

Outra forma de promoção da discussão institucional foi a manutenção de um link do GT-Igualdade Racial no portal do MP-SP. Na página do Grupo estão disponíveis indicações bibliográficas, documentos sobre cotas raciais e legislação sobre o tema. Houve uma preocupação constante com registro e divulgação dos trabalhos do Grupo por meio do site do MP-SP.

Algumas críticas relacionadas às estratégias do GT-IR, entretanto, devem ser mencionadas. Em primeiro lugar, dentre os quatro professores palestrantes das reuniões de formação, havia apenas uma mulher e somente um negro. Além disso, todos os convidados são professores e acadêmicos. Não houve uma tentativa de aproximação de ativistas desvinculados da academia.

A principal justificativa para essa escolha foi a de que os integrantes não estavam ainda preparados para o contato próximo com movimentos sociais. Eles precisariam primeiro formar seu conhecimento sobre o tema e consolidar as estratégias e objetivos do Grupo, para depois fazer esse diálogo. Foi possível perceber um medo bastante grande dessa aproximação, que não foi realizada pelo Grupo. O GT-IR também não conseguiu se organizar para "sair da toca", conforme fala de uma servidora. Uma ideia, por exemplo, era visitar um quilombo, objetivo importante para alguns integrantes do GT, pois permitiria uma maior sensibilização sobre o tema.

Ainda, apesar das reuniões de formação serem abertas para a participação de todos os membros do MP-SP e serem divulgadas por meio dos Boletins Informativos e do próprio site da instituição, a participação de pessoas de fora do GT-IR foi pequena. O foco da atuação do GT-Igualdade Racial, conforme seus 
integrantes, era capacitar os próprios participantes do Grupo, para que se tornassem a referência nas questões de enfrentamento ao racismo. No entanto, conforme fala de um promotor em uma reunião, o alcance dessas medidas ainda é muito limitado:

O promotor, quando sai do banco da faculdade, ele integra uma elite branca em uma sociedade em que o racismo é estruturante. Ainda assim ele quer mudar o mundo. Mas ele não conhece o mundo que vai mudar. Não tem ideia de onde vai ser inserido e a tendência é reproduzir o racismo, a estrutura social racista, embora ele mesmo não se ache racista. Nós temos que criar estratégias para que nossas ações aqui sensibilizem de maneira mais contundente a grande massa dos promotores. Ainda é muito pouco o que fazemos.

Podemos concluir que o GT-Igualdade Racial realizou uma importante atuação ao priorizar reflexões sobre o racismo institucional e sobre branquitude, promovendo um autoexame da instituição enquanto (re) produtora de racismo e provocando os membros do MP a perceberem seu papel individual para a manutenção das desigualdades raciais. $O$ Grupo entende que, para provocar transformações de comportamento com relação ao racismo, não basta apenas promover formações sobre o tema, é preciso realizar estratégias de sensibilização, "aliando conteúdo com emoção". Ainda assim, esse foi apenas um passo inicial de uma política que deveria ser permanente e constantemente ampliada.

\section{RETRATOS DA DESIGUALDADE: $O$ PRIMEIRO CENSO RACIAL DO MP-SP}

Quando entrei no MP, não sabia onde era a agência do Banco do Brasil. Eu fui ao banco mais próximo e falei, Olha es- tou sendo admitida no MP, estou vindo aqui para abrir uma conta. Aí a menina perguntou para mim: Você é auxiliar de promotoria? Eu falei, Eu não. Aí ela falou, Então você é oficial? Falei: Não, sou analista de promotoria, sou assistente social, e fui orientada a vir aqui. Ela respondeu, Aqui a gente atende só promotor, então você tem que ir ali. Eu entendo que ela queria saber qual era a função que eu tinha para poder me orientar, mas por que eu não poderia ser analista ou promotora? Ela já começou pela função mais baixa, de nível de escolaridade menor, que é aquela que ela supôs ser onde os negros estão. É algo tão natural que a pessoa nem percebe.

Essa fala de uma servidora negra entrevistada, integrante do GT-Igualdade Racial, demonstra, dentre outras questões relevantes, a naturalização da ideia construída historicamente de que pessoas negras são menos capazes para ocupar posições de destaque na esfera política e nas instituições do sistema de justiça.

Desde a primeira reunião, houve um consenso quanto ao problema da ausência de negros no Ministério Público de São Paulo, e dos estereótipos que associam cor da pele a "competência" e "distinção social". Uma das prioridades do Grupo foi buscar a aprovação de cotas raciais nos concursos do MP-SP para promover transformações nesse cenário de desigualdade.

Apesar do contexto atual de implementação de ações afirmativas por diferentes instituições do sistema de justiça, foi possível identificar uma enorme rejeição com relação às cotas raciais no MP-SP ${ }^{8}$. Conforme ${ }^{8}$ Diversos órgãos do sistema de justiça estabeleceram cotas raciais nos concursos de ingresso às carreiras, dentre os quais podem ser citados o Supremo Tribunal Federal, o Tribunal Superior do Trabalho, o Ministério Público da Bahia, que teve seu sistema de cotas valida- 
um promotor entrevistado, as cotas raciais ainda são "um grande tabu":

Uma grande dificuldade é lidar com essa classe de procuradores e promotores de justiça que foram durante muitos anos embasados por argumentos anticotas: cota gera mais desigualdade, não faz sentido, depende do esforço de cada um. Esse ideal de meritocracia, que não leva em consideração o desenvolvimento histórico do país. Tudo isso gera base argumentativa para uma classe que pouco estuda sobre o tema e utiliza apenas argumentos prontos. Essa é a classe da maioria do MP.

O GT-Igualdade Racial procurou agir de forma estratégica e ponderada para "contornar o eleitorado majoritariamente contrário" às cotas. Sua principal estratégia foi a realização do primeiro censo racial dos membros do MP-SP. Para o GT, o censo instigaria o debate na instituição, e seria um passo importante para a comprovação da necessidade de implementação de políticas de ação afirmativa.

O Grupo decidiu realizar um censo tanto dos servidores, quanto dos promotores e procuradores da instituição. O GT identificou que um questionário enviado periodicamente pelo Departamento de Recursos Humanos para todos os servidores do MP-SP continha uma pergunta sobre cor/raça. Dessa forma, com relação aos servidores, não seria necessário realizar um novo questionário. Já com relação aos promotores e procuradores, não havia qualquer informação sobre o quesito raça/cor, e os integrantes do GT tiveram que discutir como esses dados seriam obtidos.

A aplicação do questionário aos promotores

do pelo Conselho Nacional do Ministério Público (CNMP) o Ministério Público do Estado do Paraná, e a Defensoria Pública do Estado de São Paulo. e procuradores foi analisada sob diferentes ângulos: o momento adequado para o envio, o formato do questionário, a abordagem das questões da raça/cor e da autodeclaração, e a obrigatoriedade da resposta. Preocupados com a reação dos membros do MP-SP, alguns integrantes do Grupo até sugeriram enviar o questionário junto com outras perguntas, para que o tema racial passasse despercebido e não provocasse objeções. Concluiu-se, entretanto, que um dos intuitos da realização do censo era justamente dar visibilidade para o debate da desigualdade racial na instituição.

O questionário foi enviado em junho de 2015, com um prazo de 30 dias para seu preenchimento. Foi possível verificar que o censo racial provocou grandes resistências, demonstrando a forte opinião contrária às cotas raciais da maioria dos promotores e procuradores. Apesar da resposta ser considerada obrigatória pela Corregedoria e Procuradoria Geral do MP-SP, e da extensão do prazo por 30 dias, 18\% dos membros da instituição não responderam ao questionário.

Segundo um entrevistado, alguns promotores se recusaram expressamente a participar do censo: "Colegas falaram com o Procurador Geral de Justiça. Disseram: Eu não vou responder, não posso ser obrigado a isso. Um colega colocou: Não quero responder porque acho que todo mundo é igual". Em notícia no portal da Associação Paulista do Ministério Público, o posicionamento de um promotor também ilustra esse cenário de reprovação:

O Ato Normativo conjunto da PGJ e da Corregedoria-Geral, no meu entendimento, é no mínimo inoportuno. Acho que obrigar os colegas a declarar algo que diz respeito ao seu patrimônio de in- 
timidade não é, de forma alguma, a meIhor alternativa para uma instituição que se presume democrática e que pretende lutar pelo estado democrático de direito.

A notícia também aponta a opinião de outro promotor: "Não sou favorável à realização desse censo. É um tipo de censo que corre, sim, o risco de fomentar ou criar uma segregação que é inexistente dentro do MP, de incentivar algum tipo de acirramento que hoje não existe".

Em geral, os integrantes do GT-IR foram bastante críticos em relação aos membros do MP-SP que se posicionaram contra o censo racial. Uma servidora, especificamente sobre o argumento de que o censo incentivaria algum tipo de racismo, questionou durante a entrevista:

Qual é a primeira coisa para alcóolicos anônimos? Reconhecer o problema. Então a gente divide pessoas como brancos e negros porque é assim que somos tratados. O Brasil é um país racista, temos que assumir. Enquanto a gente naturaliza, fica com está. A gente precisa mexer com isso.

Um promotor, por sua vez, argumentou em entrevista:

Existe esse discurso: eu não sou branco, não sou negro, sou ser humano. Esse discurso é o discurso mais estelionatário que temos visto hoje no mundo jurídico. As pessoas se camuflam com base nesse suposto raciocínio científico. Não adianta dizer que as pessoas não são brancas ou negras, se continuam sendo discriminadas como negras; se por conta do fenótipo associado ao negro as pessoas são barradas por seguranças, perdem empregos, tem menos possibilidade de ascender na vida.
No entanto, ele mesmo ponderou que o GT-Igualdade Racial deveria ter realizado mais ações de sensibilização dos membros do MP-SP antes de implementar o censo:

A maneira como foi colocado o censo poderia ter sido um pouco mais aperfeiçoada. Faltou um pouco de esclarecimento das pessoas. Partindo da premissa de que teria certa resistência, e da personalidade de alguns promotores de sempre questionar, poderia ter sido melhor apresentado, mas isso não impediria as críticas também.

Por outro lado, segundo vários promotores, houve suspeita de que alguns membros do MP-SP realizaram declarações falsas com o objetivo de enfraquecer a medida: Em entrevista foi feito o seguinte comentário: "Pessoas se declararam negras falsamente exatamente porque iríamos encaminhar proposta de cotas e, como são contrários, queriam maquilar os dados. Temos essa suspeita porque foi comentado em redes sociais".

Foi discutida pelo GT a necessidade de responsabilização, através de falta funcional, dos promotores que se recusaram a responder ao censo. Para alguns participantes do Grupo, aqueles suspeitos de realizarem declarações falsas deveriam ser denunciados por falsidade ideológica. A conclusão, no entanto, foi de que o GT-IR deveria trabalhar para a sensibilização dos membros do MP, e que cabia apenas ao Procurador Geral da Justiça decidir sobre outras medidas.

Os resultados do censo racial, com a autodeclaração de 82\% (1608) dos promotores e procuradores do MP-SP, indicam uma desigualdade racial alarmante na instituição. Os membros do MP-SP deveriam identificar-se com uma das seguintes categorias: negro, 
branco, amarelo e indígena. 9 Pouco menos de 4\% (56) dos promotores e procuradores do MP-SP se declaram como negros, enquanto 93\% (1493) se declaram como brancos. Finalmente, 3\% (55) classificam-se como amarelos e 0,3\% (4) como indígenas. No Estado de São Paulo, pretos e pardos representam 35\% do total da população (IBGE, 2010)

Conforme membros do GT, o cenário de desigualdade racial é ainda pior, tendo em vista a suspeita de declarações falsas. Em reunião, um promotor comentou: "A gente supõe que esse número de 56 negros está superestimado. Sinceramente eu não consigo contar 56 membros na carreira. Evidentemente que não são 56. A situação é mais dramática ainda".

Uma importante medida do GT-Igualdade Racial foi realizar uma análise dos dados levando em consideração o cargo e a data de posse (nível de carreira e tempo) dos membros do MP-SP. Ainda, a partir da sugestão de uma promotora, e da compreensão de que ser mulher e ser negra "são fatores de exclusão agregados", os integrantes decidiram elaborar relatórios com dados que relacionassem gênero e raça.

O resultado dessa análise evidenciou que a maioria (54\%) dos promotores negros ingressou na instituição há mais de 20 anos atrás. Além disso, explicitou a desigualdade de gênero no MP-SP: $64 \%$ dos promotores e procuradores da instituição são homens, mas totalizam 48\% da população do Estado (IBGE, 2010). Foi possível verificar também que as mulheres negras são as que possuem

\footnotetext{
O Grupo, a partir de um levantamento bibliográfico, concluiu "ser mais adequado, por se tratar de reclamo do movimento negro para valorização da afro-descendência, que os questionários a serem enviados a servidores e membros contemplem como critério de raça/ cor o termo negro, com a indicação de que tal termo compreende aqueles que se declaram pretos e pardos" (Memórias da 2a reunião ordinária, 10 de dezembro de 2014).
}

maior exclusão na instituição, pois apenas 8 promotoras se autodeclararam negras.

Os resultados do censo dos servidores, realizado a partir das respostas de $80 \%$ dos funcionários (3.989) em 2015, apontaram que também existe uma grande desigualdade em termos raciais com relação aos servidores do MP-SP: aproximadamente $80 \%$ dos servidores se declararam brancos (3.204), $14 \%$ negros (549), $6 \%$ amarelos (221), e 0,4\% indígenas (15).

Outro dado que ilustra esse contexto de exclusão é a porcentagem de negros dentre os analistas de promotoria que são assistentes jurídicos, cargo que exige nível de escolaridade superior e formação em Direito: $91 \%$ são brancos (892), 0\% indígenas (2), $6 \%$ negros (55) e 3\% amarelos (26). Por outro lado, diferentemente do que ocorre com os promotores e promotoras negros, há um equilíbrio de gênero entre os servidores negros (49,7\% homens e 50,3\% mulheres).

Por fim, o dado que mais chamou a atenção do GT-Igualdade Racial com relação aos servidores foi a "distribuição por cor/etnia e antiguidade". Amarelos, brancos e indígenas possuem uma distribuição parecida por antiguidade, com proporção maior (cerca de 50\%) de servidores com até 5 anos de MP. Já a maior parte dos servidores negros (55\%) está na instituição há mais de 20 anos. Uma servidora negra, sobre o assunto, comentou em entrevista:

Você viu como foi o censo dos servidores? Mostrou uma realidade triste. Quando eu entrei no MP, há 20 anos atrás, era bem maior a proporção de negros. A profissionalização dos concursos não permite mais que os negros entrem na instituição. Hoje, acho que se eu prestasse concurso de nível médio, dada a concorrência, não con- 
seguiria ser aprovada. Houve uma exclusão natural dos negros ao longo dos anos.

Podemos concluir que a elaboração do primeiro censo racial do MP-SP foi uma importante conquista do Grupo e demonstrou uma desigualdade racial gritante na instituição. $\bigcirc$ GT procurou divulgar os resultados nos meios de comunicação institucionais e na grande mídia, mas não obteve grande visibilidade.

Inicialmente, o Grupo acreditava que o caminho mais fácil para a implementação de cotas raciais seria a aprovação de uma resolução do Conselho Nacional do Ministério Público (CNMP) exigindo a implementação de cotas raciais para todos os Ministérios Públicos brasileiros. ${ }^{10} \mathrm{O}$ GT achava que $\mathrm{O}$ CNMP iria elaborar essa resolução porque, em março de 2015, o Conselho afirmou, por unanimidade, a legalidade das cotas raciais no Ministério Público da Bahia. Além disso, as cotas raciais no Poder Judiciário e na Defensoria Pública já foram aprovadas pelo Conselho Nacional de Justiça e pelo ConseIho Superior da Defensoria Pública do Estado de São Paulo.

No entanto, apesar da resolução ter entrado na pauta do CNMP nas plenárias dos dias 28 e 29 de julho de 2015, o Conselho não analisou o tema. Dessa forma, os integrantes do Grupo refletiram que não poderiam contar apenas com o CNMP para a aprovação das cotas, e que deveriam priorizar estratégias internas ao MP-SP.

O GT-Igualdade Racial elaborou então uma proposta para estabelecimento de cotas raciais no MP-SP. Assim como na realização do censo racial, o Grupo discutiu inúmeras

o $O$ Conselho Nacional do Ministério Público (CNMP) foi instituído pela Emenda Constitucional 45/2004 e é integrado por membros do MP, do Judiciário e da sociedade civil, com atribuição de realizar "a fiscalização da gestão administrativa e financeira, o controle da atuação dos promotores e procuradores de Justiça e a escolha de um corregedor nacional entre os membros que o integram". questões sobre o desenvolvimento dessa proposta, para que não provocasse tantas resistências e que tivesse alguma chance de aprovação. Foram debatidas: a porcentagem da reserva de vagas, as etapas e exigências dos concursos ${ }^{11}$, a forma de classificação racial (auto e/ou heteroclassificação, critérios fenotípicos e/ou de ascendência), os cargos incluídos, a forma de fiscalização das declarações raciais e de monitoramento da política, e o momento da entrega da proposta ao Procurador Geral da Justiça.

Uma importante discussão no GT, que ilustra um de seus principais dilemas, foi sobre a necessidade de exigir-se uma pontuação mínima para os candidatos pelas cotas raciais. Alguns integrantes do Grupo indicaram, como exemplo, as cotas para deficientes, que não têm efetividade, e afirmaram que o mesmo ocorrerá com as cotas raciais se for mantida essa exigência. Este debate foi resolvido pela conclusão de que seria impossível a aprovação de uma proposta sem a exigência da pontuação mínima. Esta decisão foi muito frustrante para participantes do Grupo, pois as reuniões de formação demonstraram que, no Brasil, os negros não têm as mesmas oportunidades de ensino do que os brancos, e que a exigência de padrões mínimos acaba reforçando essa injustiça.

O Grupo formalizou, no dia 28 de janeiro de 2016, a entrega da proposta ao Procurador Geral de Justiça'2 ${ }^{12}$. Conforme o texto, 20\% das vagas dos concursos para promotor, ser-

A seleção para o cargo de promotor no MP-SP é organizada em três etapas. A primeira é uma prova de múltipla escolha, de caráter eliminatório; em seguida, vem uma prova escrita e, por último, a prova oral, que também tem caráter eliminatório e classificatório. Como filtro social contribui não só o nível de exigência do concurso de entrada, mas também o requisito de três anos de atividade prévia (CESEC, 2016, p.64). No GT-IR também foi discutida a importância de incluir mulheres e negros na composição da banca que realiza as entrevistas dos candidatos na última fase.

12 Foi realizada uma cerimônia de entrega da proposta ao Procurador Geral de Justiça pelo GT-Igualdade Racial, em que alguns integrantes do Grupo, servidores e promotores, falaram sobre a importância da medida. Esse momento foi noticiado no portal de notícias do site institucional do MP-SP. 
vidor e estagiário deveriam ser reservadas para os candidatos que se autodeclararem negros (pretos e pardos). Os cargos em comissão não foram incluídos na proposta. Há previsão para que uma Comissão de Monitoramento e Avaliação julgue eventuais casos de autodeclaração falsa. O Grupo estabeleceu que, para essa avaliação, é essencial considerar o fenótipo dos candidatos, "tendo em vista o objetivo de contemplar o segmento que sofre com o racismo em todas as suas consequências".

Para que a proposta seja implementada, ela precisa ser aprovada pelo Órgão Especial do Colégio de Procuradores, órgão responsável pela administração interna do MP-SP e presidido pelo Procurador Geral. Conforme colocação de um promotor do GT-IR em uma reunião, a chance dessa aprovação é pequena. O Órgão Especial é formado por 40 membros: 20 procuradores eleitos e 20 "membros natos", que ocupam o posto por critério de antiguidade. Segundo este promotor, "o Órgão Especial é um espaço insuportavelmente antidemocrático na instituição, de muito conservadorismo, onde há grande resistência a ações afirmativas".

Para o GT, a implementação das cotas exigirá muita negociação política, além do esforço conjunto dos movimentos sociais, das organizações da sociedade civil e da mídia para pressionar os procuradores do Órgão Especial do Colégio dos Procuradores. O exemplo a ser seguido é a aprovação das cotas na Defensoria Pública do Estado de São Paulo, que só foi conseguida através da pressão realizada pelos movimentos sociais.

Até o momento final dessa pesquisa, a proposta ainda não foi colocada em pauta para discussão pelo Órgão Especial. Tendo em vista a falta de diálogo do GT-Igualdade Ra- cial com movimentos sociais e o encerramento dos trabalhos do Grupo, é possível que o GT tenha dificuldades para promover uma mobilização e pressionar os procuradores pela sua aprovação.

Podemos concluir que, apesar da apresentação da proposta de cotas ao Procurador Geral de Justiça ser uma importante conquista, a possibilidade de implementação dessa ação afirmativa ainda está bastante distante, mesmo com o movimento atual de implementação de cotas raciais em outras instituições do sistema de justiça. A realização de medidas de forma ponderada, para "contornar o eleitorado contrário", talvez não tenha sido a melhor opção nesse caso, pois os avanços provocados pelo GT-Igualdade Racial não foram suficientes para combater a forte rejeição às cotas raciais por grande parte dos membros do Ministério Público de São Paulo.

\section{MAPEANDO A (IN)AÇÃO DO MP-SP NOS CRIMES DE RACISMO E INJÚRIA RACIAL}

Além de estratégias de sensibilização sobre o tema da discriminação e da busca por ações afirmativas nos concursos, o GT-Igualdade Racial discutiu a atuação do MP-SP na repressão dos crimes de racismo e injúria racial. ${ }^{13}$ Cabe ao Ministério Público a promoção da ação penal pública, portanto é papel da instituição promover a ação judicial na ocorrência desses crimes.

A acusação penal é uma função tradicional do MP e uma prioridade na instituição desde o início da sua existência. No entanto, segundo integrantes do GT, quando se tra-

3 A injúria racial, descrita no artigo 140, parágrafo 30, do Código Penal, consiste em uma ofensa contra uma única pessoa, atingindo-Ihe o decoro e a percepção que ela tem de si mesma, caracterizando a chamada ofensa à honra subjetiva. A pena é de reclusão de um a três anos e multa. Já o racismo, tipificado na Lei 7.716 de 1989, é compreendido como discriminação a qual tem como objeto um grupo inteiro de pessoas. Há um maior rigor na punição do racismo, tornando-o um crime imprescritível e inafiançável, além da prisão e das multas previstas pela legislação (Santos, 2015, p.186). 
ta de crimes de racismo e injúria racial, há um evidente desinteresse entre os promotores da instituição. Em uma das reuniões, um promotor afirmou que muitos "tratam o racismo como mais um crimezinho isolado, de menor potencial ofensivo, e não sabem dimensionar seu tamanho".

Outro promotor afirmou que há um despreparo dos membros do MP, que não são qualificados para atuar nesses casos:

Veja, eu fui o autor da sugestão, no ano de 2002, para inclusão do tema da Lei 7716/89 (Lei do Racismo) no concurso do $\mathrm{MP}$, porque até então não era nem cobrado. Você não aprende sobre o tema na faculdade, não tem no currículo e não é cobrado no concurso. A tendência maior é o promotor não saber, é ser um profissional que nunca ouviu falar ou que nunca estudou o tema. (...) Até hoje enfrentamos isso. Não há qualificação adequada dos colegas na matéria, o que reflete muito na solução inadequada dos casos.

Em decorrência da formação inadequada e da falta de debate institucional sobre o tema, esse mesmo promotor indicou que não há uma diretriz segura para a atuação do MP nesses crimes: casos de injúrias qualificadas pelo elemento racial são tipificados como injúrias simples e, consequentemente, tratados como infrações penais de menor potencial ofensivo; há por vezes uma confusão entre os crimes de racismo e as injúrias qualificadas, gerando a impunidade ou a tomada de providências processuais inadequadas; e há discordâncias sobre o cabimento da suspensão condicional do processo (artigo 89 da Lei 9099/95) em casos com pena mínima não superior a um ano.

A principal estratégia do GT-IR para reverter esta situação foi realizar um levantamento atualizado, no sistema de informação do MP-SP, das denúncias e dos arquivamentos referentes aos delitos de racismo e injúria racial. O objetivo do Grupo era obter, através do retrato estatístico, ferramentas para a realização de medidas de capacitação e sensibilização dos promotores em relação ao tema. Além disso, seria uma forma de identificar fragilidades da investigação policial para posterior apresentação às instituições da segurança pública.

Trata-se de uma iniciativa inovadora, pois as instituições do sistema de justiça geralmente não se preocupam com levantamentos estatísticos e nem com a exposição desses dados (Moura, 2013, p.17). Divulgar essas informações é uma forma de dar visibilidade institucional para o tema, mostrando tendências que não são imediatamente detectáveis, e também uma forma de prestação de contas para a população, uma iniciativa que aumenta a transparência institucional.

Ao iniciar-se o levantamento logo foi feita uma descoberta que ilustra o desinteresse da instituição com relação a esses crimes. No sistema informacional do MP-SP, os casos de injúria racial eram cadastrados na mesma categoria que os casos de injúria simples, impossibilitando a rápida identificação dos arquivamentos ou denúncias com elementos raciais. O GT enviou um ofício ao Procurador Geral da Justiça solicitando a alteração do sistema para facilitar futuras pesquisas.

Para o Grupo, o resultado do levantamento revelou que o Ministério Público tem atuação pouco expressiva em casos de racismo e de injúria racial. Foram identificados 758 casos no Estado inteiro, desde outubro de 2011 até fevereiro de 2015, um número considerado muito baixo pelos integrantes do 
GT. Há também um número maior de arquivamentos do que de denúncias, indicando a dificuldade da persecução penal desses delitos. O levantamento mostrou que foram arquivados $75 \%$ dos casos de racismo e $85 \%$ dos casos de injúria racial.

Os participantes do Grupo discutiram que o número de representações e inquéritos de racismo e injúria racial não reflete a realidade social do racismo no Estado de São Paulo. Concluíram que um grande número de casos não é registrado por nenhuma instituição do sistema de justiça. Apontaram inúmeros obstáculos que dificultam a denúncia desses crimes pelas vítimas, dentre eles: a desconfiança da população negra com relação ao sistema de justiça, desencorajamento nas próprias instituições de segurança pública, falhas de atendimento pelas autoridades policiais, como casos em que as ocorrências são anotadas como injúria e difamação simples, e o desconhecimento sobre os direitos e formas de registrar ocorrências. Uma servidora, nesse sentido, explicou durante uma reunião:

A pessoa que está na Vila Matilde, onde eu moro, e sofre crime de injúria racial, não vai saber dizer se aquilo é injuria ou racismo. Quando ela chega na delegacia para registrar o $\mathrm{BO}$, que é o ponto inicial, ela vai ser desestimulada, porque tem tantos outros crimes lá. Eu acho que eles não dão a importância que deve ser dada. (...) e a estrutura das delegacias é péssima, sem condições. Tem um desencorajamento grande.

Diversas sugestões foram feitas para que as demandas raciais passassem a chegar à instituição. Para uns, seria necessária uma campanha institucional do MP-SP, sobretudo nas redes sociais, que convocasse as víti- mas de racismo a se aproximarem da instituição. Para outros, seria importante que o MP fosse até às vítimas, "divulgando o trabalho da instituição e demonstrando que é parceiro na luta". Também foi sugerida a criação e divulgação de canais específicos para que as pessoas denunciassem ao MP-SP as infrações relacionadas ao racismo e intolerância. ${ }^{14}$

No entanto, nenhuma medida nesse sentido foi realizada. Também não houve uma preocupação em analisar e divulgar os dados obtidos com o levantamento. Os dados apresentados tanto para os integrantes do GT, quanto disponibilizados no site do MP-SP dizem apenas os números de inquéritos e termos circunstanciados por tipo penal (crime resultante de preconceito de raça/ cor ou injúria) e seu status (arquivado, denunciado, em andamento, evoluído, juntado, apensado). As informações não estão reunidas de forma simplificada e acessível a não-especialistas.

O GT-Igualdade Racial deliberou ser necessária uma pesquisa para aprofundar o levantamento das causas de arquivamento dos crimes de racismo e injúria racial. A suspeita é de que a análise indicará que certos membros do MP-SP não dão a devida importância a esses crimes, demonstrando o "preconceito interno" de quem arquivou o procedimento. A pesquisa acabou não sendo realizada por falta de tempo e organização.

Importante mencionar a preocupação de que essa pesquisa provocasse conflitos com os demais promotores e violasse sua independência funcional. Um promotor afirmou em entrevista:

${ }_{14}$ O canal de comunicação para esses crimes é a Ouvidoria do MP_SP, que possui várias alternativas de contato: telefone, e-mail, atendimento presencial ou formulários para preenchimento online. No site do MP-SP há também a indicação de e-mails para contato por área de atuação do MP-SP, como direitos humanos, criminal e infância e juventude. 
Quando se começa a analisar os motivos do arquivamento, a pegar caso a caso e ver qual promotor arquivou, é preciso tomar mais cuidado. Um órgão de assessoria não pode corrigir o trabalho de um promotor específico. Esse cuidado temos que ter sempre. Faz parte da saúde da instituição o promotor ter sua independência funcional. Prezar isso é importante não só para o promotor mas também para a população.

Para contornar estes problemas, foi discutido que o levantamento apontasse apenas as aberrações na atuação dos promotores, práticas que fossem explicitamente contrárias à doutrina e jurisprudência majoritárias. Foi também decidido que nenhum nome de promotor ou procurador seria mencionado. Identifiquei que há uma evidente tensão, no caso dos crimes de racismo e injúria racial, entre a definição de diretrizes institucionais para uma atuação mais adequada de persecução desses delitos e o princípio da independência funcional dos promotores e procuradores.

Cabe relatar a iniciativa individual de um promotor integrante do GT-IR, que elaborou um requerimento ao Conselho Superior do Ministério Público de São Paulo (CSMP-SP) para a criação de um núcleo de Promotores de Justiça com atribuição para atuar especificamente em todos os inquéritos policiais e processos sobre os crimes de racismo e injúria qualificada.

Uma das inspirações para a elaboração desse requerimento foi a experiência do Grupo Especializado em Violência Doméstica (GEVID) do MP-SP. Assim como no caso do racismo, não chegava ao MP-SP um grande número de casos de violência doméstica. $O$ trabalho do GEVID, ao acolher as vítimas e atuar de forma proativa junto à população, criou melhores condições para que se revelasse a real dimensão da demanda das muIheres pelo combate à violência doméstica. Recentemente o GEVID foi inclusive transformado em Promotoria, adquirindo caráter permanente no MP-SP.

O requerimento defende que a especialização nesta área promoveria a discussão entre os promotores criminais acerca do tema, criando bases para entendimentos comuns. Inclui também a necessidade de definição de competência para os crimes de racismo e injúria racial realizados pela internet, e a criação de um corpo técnico especializado em informática para auxiliar na investigação desses crimes. Até o final dessa pesquisa, não houve resposta ao requerimento. Em minha opinião, essa iniciativa poderia ter sido elaborada em conjunto com o GT-Igualdade Racial e teve seu alcance limitado pelo fato de ter sido feita individualmente.

Por fim, o GT-IR não discutiu a possibilidade de realizar um mapeamento da atuação das Promotorias de Tutela Cível e de Direitos Coletivos em casos de discriminação racial, mesmo constatando que também não há um tratamento uniforme para esses casos e que são poucas as demandas raciais lá noticiadas. Os instrumentos jurídicos de defesa dos direitos coletivos, como Ações Civis Públicas e Termos de Ajustamento de Condutas, possibilitam um âmbito de reprovação de condutas racistas diferente da esfera penal, com outra linguagem. Conforme uma promotora:

Na área criminal tem uma pessoa, um ser humano que é o autor do fato, e ponto. Ele tem que ser determinado pela lei. Já a área dos direitos difusos trata de interesses transindividuais. Como o bem que 
está protegendo é difuso na sociedade, ou coletivo, todas as pessoas vão ser beneficiadas. Há um caráter preventivo, pedagógico, e faz efeito direto para muita gente. (...) Quando fiz um TAC criando cotas para modelos negras no Fashion Week, por exemplo, muitos pais falaram, Doutora, pela primeira vez minha filha se viu. O sonho dela é ser modelo, mas nunca viu uma modelo negra.

Acredito que seria importante verificar de que forma o MP vem atuando nessa seara e quais são as possibilidades dessa atuação. Podemos concluir que o GT-Igualdade Racial não conseguiu promover uma reflexão institucional sobre os crimes de racismo e injúria racial e nem realizar medida efetivas para aprimorar a atuação do MP-SP na persecução desses casos.

\section{ACUSAR E DEFENDER: CONTRADIÇÕES DO MINISTÉRIO PÚBLICO}

A constituição deu funções bipolares, esquizofrênicas ao Ministério Público. Em tese seriam compatíveis, mas a história as fez incompatíveis. A população mais encarcerada no Brasil é a pobre e preta. Há um preconceito, uma eleição clara e massiva da população que é perseguida pelo sistema penal. E existe uma necessidade do MP tornar efetivos os direitos fundamentais da Constituição. (...) Acaba gerando confusão dessa população que tem em tese seus direitos fundamentais defendidos pelo MP. De um lado é perseguida pela instituição, por outro tenta ser protegida. Então quem é esse MP?

A fala transcrita acima, da entrevista de uma servidora do GT-Igualdade Racial, ilustra dois dos principais desafios relacionados ao papel do MP-SP na luta antirracista. Como a instituição pode estabelecer uma relação de confiança com a população negra brasileira se ela contribui ativamente para seu encarceramento? De que forma o MP-SP pode combater as sistemáticas violações de direitos da população negra que caracterizam a ação policial e o funcionamento do sistema prisional brasileiro se a própria instituição é responsável por demandar que acusados sejam punidos?

Esses questionamentos decorrem dos novos objetivos do Ministério Público estabelecidos na Constituição Federal de 1988. Ao ter sua atuação ampliada para incluir a área dos direitos difusos e coletivos e do controle externo da atividade policial, o MP ganha um duplo papel: ao mesmo tempo em que atua na defesa do Estado, como fiscal da lei e titular da ação penal, deve agir também em defesa da sociedade, eventualmente contra esse mesmo Estado.

Essa "dupla atribuição" estabelecida pela Constituição acaba por prejudicar a atuação do MP no enfrentamento ao racismo especialmente em dois importantes âmbitos: estabelecer uma relação de confiança e diálogo com a população negra brasileira, e enfrentar as violações de direitos realizadas pela atividade policial e pelo sistema prisional.

O GT-IR constatou que a população não confia no MP-SP para realizar denúncias de racismo e encaminhar demandas de combate à discriminação. Em decorrência da sua tradicional função de acusação penal, o Ministério Público é associado com o sistema criminal, e não com a promoção da igualdade racial. Desde a primeira reunião, - GT-Igualdade Racial estabeleceu como objetivo justamente fortalecer a imagem do MP como defensor da sociedade e não do 
Estado. Em entrevista, uma servidora afirmou:

Na minha visão, o principal papel do GT é quebrar um paradigma dentro da instituição. A instituição nasceu para servir a população, então o grande papel do GT é transformar a cara da instituição para tratar realmente dos problemas da população, para que as pessoas possam vir bater na porta do MP e saber que elas serão atendidas. Temos que levar promotor de justiça na periferia para mostrar que ele não é o cara que vai condenar as pessoas, prender seu pai e sua mãe. Mostrar que o promotor de justiça é alguém em quem ele pode confiar.

Foi criado um subgrupo para elaborar um trabalho de aproximação com comunidades vulneráveis. A proposta inicial era organizar palestras em escolas, a serem ministradas por promotores de justiça, para esclarecer a missão constitucional do MP e trabalhar temas de direitos humanos e da igualdade racial. Esse projeto, entretanto, não foi realizado.

Uma possível explicação é que prevaleceu a própria insegurança dos integrantes do GT-IR em relação à atuação da maioria dos membros do MP-SP. Acham impossível afirmar para as comunidades vulneráveis que o MP-SP é um espaço de acolhimento quando, de fato, acreditam que muitas vezes não serão acolhidas pela instituição.

Segundo os integrantes do GT, há uma cultura institucional de criminalização no MP-SP, que muitas vezes estimula comportamentos contraditórios com relação à defesa dos direitos humanos e dos interesses sociais por parte de promotores e procuradores. Conforme fala de um promotor na última reunião do GT-IR, a cultura punitivista é extremamente forte no MP:
Entrei no MP pensando que iria contribuir para mudança social. Quando entrei no MP passei a endurecer, a ter posturas que não eram as minhas posturas essenciais, que foram sendo incorporadas pelos corredores de fórum, pelos lanches com promotores e juízes. Ao longo dos primeiros anos do MP passei por um processo de deterioração muito grande, a ponto de achar normal a quantidade de prisões processuais que existem, a quantidade de internações de adolescentes em conflito com a lei. Pesava a caneta como todo mundo e achava bonito. Hoje trabalho na infância e juventude e sou visto como louco naquele ambiente, um louco que diz com todas as letras que a internação do jeito que é hoje, pelo menos em SP, não serve para nada. Serve na verdade para o contrário do que a lei determina que seja a medida socioeducativa. Pauto minha atuação para evitar ao máximo internação, ao contrário do que é historicamente a prática daquela promotoria. Digo isso para ressaltar o quanto é forte essa cultura institucional e o processo de alienação pelo qual eu passei.

Participantes do GT comentaram em reunião e entrevista que a atuação da Corregedoria do MP-SP no momento do estágio probatório contribui para a manutenção dessa cultura punitivista na instituição. Assim que ingressam no MP, os promotores passam por um período de avaliação até o seu vitaliciamento, chamado de estágio probatório, com duração de dois anos. A Corregedoria do MP-SP é a responsável pelas funções correicional e de orientação daqueles que recém ingressaram na carreira. O Grupo indicou que os promotores em estágio probatório preferem não ir contra a 
cultura punitivista, com medo dos possíveis prejuízos para suas carreiras.

Outra forma de manutenção dessa cultura, conforme fala do promotor acima, é que promotores que tem uma atuação diferente na área penal acabam sendo vistos "como loucos" e perdem a possibilidade de assumir cargos de gestão e destaque na instituição.

Além da força da cultura punitivista, foram relatados outros aspectos que dificultam a capacidade de acolhimento do MP, como a arquitetura luxuosa de sua sede, os esquemas de segurança do prédio, e a linguagem jurídica, o formalismo, e os sinais de posição social elevada de muitos promotores e procuradores.

Ainda, foi apontada a tendência de uma atuação dos promotores e procuradores sem contato direto com camadas menos favorecidas, alheia a suas demandas. Conforme fala de uma servidora do GT, "parece que os promotores nunca viram pobres e não sabem o que fazer quando precisam conversar com um".

A falta de tempo e de recursos também limita a capacidade de atuação dos promotores em projetos na periferia. Conforme um promotor: "O aumento do trabalho processual é massacrante. Não dá para exigir a presença dos promotores nas articulações sociais, principalmente nas promotorias acumulativas. Há prazos da corregedoria e a gama de atribuições é muito grande".

É possível, por outro lado, questionar se essa dificuldade decorre realmente de uma falta de recursos materiais e humanos, ou se decorre da falta de vontade, iniciativa e formação de parte dos promotores. Estudos demonstram a existências de dois perfis muito diferentes de promotores: "promoto- res de fato", que recorrem prioritariamente a meios extrajudiciais, à mobilização de recursos da comunidade e à articulação política, e "promotores de gabinete", que se percebem como "fiscais da lei" e agem apenas reativamente, sendo mais apegados aos instrumentos judiciais (Silva, 2001).

Pesquisas também indicam que o modo como a carreira no MP está estruturada sinaliza como melhor e mais atraente a atuação numa grande cidade, a especialização dos promotores em um ou em poucos temas e o distanciamento do contato direto com a população, especialmente com seus segmentos menos favorecidos (Lemgruber, 2016, p.65).

Podemos concluir então que o MP ainda tem um longo caminho a percorrer para conquistar a confiança da população negra brasileira, caminho que passa obrigatoriamente pela ampla discussão dos elementos contraditórios de sua "dupla função" atribuída pela Constituição de 1988.

Quanto a combater as sistemáticas violações de direitos da população negra que caracterizam a ação policial e o funcionamento do sistema prisional brasileiro, já na primeira reunião do Grupo foi discutida uma proposta de aproximação com a Polícia Militar e a Guarda Civil. No entanto, na segunda reunião, essa pauta teve sua análise postergada, pois o Grupo concluiu que "deveria aprofundar as suas atividades antes de buscar aproximação com outras instituições".

O tema não foi debatido em profundidade pelo Grupo, mas apenas mencionado em falas pontuais de palestrantes convidados e nas entrevistas. Foi possível notar uma certa tentativa de desvio do tema quando o assunto vinha à tona. Um promotor justificou em entrevista: 
O tema da formação dos policiais ainda não foi tratado frontalmente no Grupo, apenas tangencialmente. Talvez tenhamos que voltar a ele, mas aí tem um problema interno. Esse assunto, a questão da violência policial, da letalidade policial, é próprio da atuação de alguns promotores criminais que lidam com o controle externo da polícia, e de promotores dos direitos humanos. Precisamos ter cuidado para que um grupo de trabalho constituído na assessoria do Procurador Geral não invada a área de atribuição do Promotor de Justiça. O Promotor de Justiça é muito cioso das suas atribuições. Precisamos ter essa preocupação.

Novamente o princípio da independência funcional foi utilizado para justificar a ausência da atuação do Grupo. Conforme a pesquisa "Ministério Público: guardião da democracia brasileira?", realizada pelo Centro de Estudos de Segurança e Cidadania, da Universidade Cândido Mendes (CESeC) UCAM), a independência funcional conferida aos membros do MP parece ser uma faca de dois gumes: por um lado, é fundamental para garantir a autonomia e independência do trabalho dos promotores, mas, por outro, pode também servir de escudo para a omissão. A mesma independência torna muito difícil o controle, a cobrança e qualquer tipo de intervenção sobre as atividades-fim e as decisões dos membros do MP, mesmo quando equivocadas, seletivas, morosas ou ineficazes (LEMGRUBER, 2016, p.64-65).

Pode-se argumentar que o desenho da hierarquia do MP-SP gera uma dificuldade adicional para a definição de diretrizes unificadas sobre esses temas. O GT-IR, como órgão de assessoria do Procurador Geral da Justiça, depende do apoio do Procurador para realizar suas iniciativas. O Procurador, entre- tanto, é eleito a cada dois anos por todos os promotores e procuradores da instituição, com possibilidade de recondução para um segundo mandato de dois anos. Para ser eleito, o Procurador precisa atuar de forma a não confrontar expressamente a cultura institucional mais punitivista/conservadora. Dessa forma, seria muito difícil que orientações institucionais nesse tema sejam estabelecidas por um órgão de assessoria do Procurador Geral de Justiça.

Além disso, apesar da independência prevista constitucionalmente, é possível questionar as reais possibilidades do MP-SP agir contra o Estado na fiscalização das atividades policiais devido à proximidade que existe entre parte dos membros do MP-SP e o Executivo. Um exemplo é o fato de que um promotor inscrito para participar do GT-Igualdade Racial não acompanhou as reuniões do Grupo por se tornar assessor do Secretário de Segurança Pública do Estado de São Paulo.

Por fim, em reunião, um promotor comentou que no contexto político atual da instituição, não há espaço para instigar uma reflexão crítica sobre o sistema penal e a contribuição do MP para o encarceramento da população negra. Segundo ele, promover essa discussão poderia causar "um desserviço a causa":

Como a gente introduz discussões a respeito de criminologia no MP, no dia a dia dos promotores criminais? Podíamos partir desse GT, mas o momento político hoje é ruim. Há um consenso de que nunca vivemos onda de conservadorismo e radicalismo, de extrema exclusão e de ódio como estamos vivendo hoje. Não é momento de estrategicamente avançarmos nessa questão. A gente se expõe 
e coloca a ideia a perder, se desmoraliza. Há um risco de desserviço a causa se você não tem noção estratégica do momento de introduzir a discussão.

Uma servidora entrevistada argumentou que a escolha por realizar uma proposta de implementação de cotas raciais, apesar da grande rejeição dos membros do MP-SP, era mais factível do que abordar o tema da violência policial e ou implementar diretrizes para uma mudança de comportamento na área criminal.

Segundo os dados do Mapa da Violência de 2016, vem aumentando a violência contra a população negra no país. Pela pesquisa, a vitimização negra, que em 2003 era de 71,7\%, mais que duplicou: em 2014 alcançou $158,9 \%$, o que significa que morrem 2,6 vezes mais negros que brancos por arma de fogo (Waiselfisz, 2016, p. 72). Além disso, o Levantamento Nacional de Informações Penitenciárias, que traz dados de dezembro de 2014, indica que a população carcerária do Brasil ultrapassou o número de 622 mil pessoas, das quais $61,6 \%$ são negros (INFOPEN, 2014 , p.6). O Levantamento aponta para a superlotação dos estabelecimentos prisionais brasileiros e para o elevado número de pessoas presas antes de serem julgadas, indicando que há evidências de que grande parte delas poderia responder ao processo em liberdade (INFOPEN, 2014, p. 15).

A pesquisa do CESec/UCAM, que coletou informações de 899 promotores e procuradores em todo o Brasil, demonstrou o "baixo envolvimento de promotores e procuradores nessas duas áreas temáticas: controle externo das polícias e supervisão da execução penal - áreas em que a atuação do MP é mal avaliada pelos próprios entrevistados, sequer é mencionada explicitamente na maioria dos websites do órgão, e é citada por menos de 1/3 dos seus membros" (Lemgruber, 2016, p.65).

Diante desse contexto, considero injustificável que o GT-Igualdade Racial não tenha feito uma reflexão e definição de iniciativas em relação aos temas da violência policial e da execução penal. Nos poucos momentos em que o Grupo tratou deste assunto, o objetivo não foi combater a postura omissa do MP-SP, por meio da elaboração de orientações institucionais padronizadas ou de mobilização da sociedade civil. As estratégias discutidas eram ou pontuais e voluntárias (participação de promotores em projetos de educação em direito em escolas), ou direcionadas para a atuação das instituições do sistema de segurança, e não para a atuação dos próprios promotores (curso de formação junto a Guarda Civil).

Concluindo, pode-se constatar que o GT-Igualdade Racial não realizou medidas efetivas para ganhar a confiança da sociedade civil e combater as violações de direitos da população negra brasileira pelas instituições do sistema de segurança pública. A pesquisa sugere a necessidade de se repensar o arranjo institucional do MP, para uma maior uniformização das suas formas de atuação, de modo que o cumprimento de suas atribuições constitucionais possa ser efetivamente realizado, bem como conhecido, cobrado e avaliado pela população.

\section{CONCLUSÕES}

O MP tem pouquíssimas pessoas negras. Eu conheço uma única mulher negra. Estamos no seguinte ponto: nós temos que tomar providências. Como uma instituição branca, na sua grande esmagadora maioria, pode deixar de usar esse protagonismo branco? (Promotora do MP-SP) 
Eu vou fazer voz das mães de filhos negros. (...) Eu me vejo preparando meu fiIho de 15 anos para a abordagem da polícia. Como a gente faz para dar voz a isso na instituição? (Servidora do MP-SP)

Esses questionamentos realizados por duas integrantes do GT-Igualdade Racial Professor Joel Rufino dos Santos, na primeira reunião de capacitação do Grupo, mostram alguns dos seus principais dilemas: como - Ministério Público de São Paulo pode dar voz às pessoas atingidas pelo racismo? Como uma instituição majoritariamente branca pode ter uma atuação eficaz de enfrentamento ao racismo?

O Grupo demonstrou uma sensibilidade inovadora para lidar com essas questões. $\mathrm{Na}$ maior parte do sistema de justiça e especialmente no Ministério Público, onde predomina fortemente o princípio da independência funcional, há uma dificuldade de uniformização de condutas. Além disso, em grande parte dessas instituições, é praticamente inexistente a participação de funcionários na elaboração de diretrizes. Finalmente, o debate sobre o racismo ainda é incipiente e essa não é uma área de atuação priorizada pelos Ministérios Públicos Estaduais.

Uma das principais conquistas do GT-Igualdade Racial, portanto, foi inaugurar um espaço de discussão sobre as práticas institucionais do Ministério Público de São Paulo para o enfrentamento ao racismo. Além disso, o GT-IR foi o primeiro grupo de trabalho do MP-SP a contar com a participação ativa de servidores interessados, reunindo 43 integrantes em diferentes cargos e funções na instituição.

O GT-Igualdade Racial também inovou ao priorizar a reflexão e a aplicação do conceito de racismo institucional. Estudos indicam a baixa incorporação desse conceito aos processos de trabalho das organizações governamentais, e a ausência ou insuficiência de experiências prévias de políticas e estratégias de erradicação do racismo institucional (Geledés, 2013b, p.7).

O Grupo realizou reuniões de formação com - objetivo de qualificar seus integrantes a identificar a reprodução do racismo no próprio Ministério Público e sensibilizá-los a provocar mudanças de impacto em suas esferas de atuação. Também se preocupou em trabalhar a questão racial a partir de uma dimensão subjetiva. O Grupo promoveu discussões sobre branquitude, instigando os seus integrantes a empreenderem uma desconstrução pessoal diária contra o racismo.

Outra importante iniciativa do GT foi a elaboração do primeiro censo racial do Ministério Público de São Paulo, que conseguiu identificar um cenário alarmante de desigualdade racial na instituição: apenas 4\% dos promotores e procuradores, e 14\% dos servidores do MP-SP declararam-se negros. O GT-Igualdade Racial também realizou o primeiro levantamento sobre as denúncias de crimes de racismo e injúria racial, concluindo que a atuação da instituição é pouco expressiva com relação a esses delitos.

No sistema de justiça, a preocupação com a coleta, análise e divulgação de dados é bastante recente. Mais recente ainda é a preocupação com a captação de dados sobre as práticas institucionais para atender às demandas de grupos sociais vulneráveis, e com a inclusão de indicadores sociais, como raça/cor e gênero nos recenseamentos e cadastros internos (Vieira \& Radomysler, 2015). Essas medidas realizadas pelo Grupo são, portanto, muito relevantes. 
A atuação do GT-Igualdade Racial, entretanto, possui inúmeras limitações. Em primeiro lugar, apesar do contexto atual de aprovação de cotas raciais em inúmeras instituições do sistema de justiça, as chances de aprovação da proposta de cotas no Ministério Público de São Paulo parecem ser pequenas, uma vez que o MP-SP já demonstrou uma enorme rejeição ao próprio censo racial realizado. Além disso, o GT-Igualdade Racial não realizou nenhuma medida para promover uma diretriz segura e um debate qualificado sobre a atuação do MP-SP nos crimes de racismo e de injúria racial. Há, por vezes, uma preocupação excessiva do GT em não violar a independência funcional dos promotores e procuradores.

Ainda, o Grupo não chegou nem perto de estabelecer um diálogo com movimentos sociais, e de refletir sobre o papel da instituição com relação às gritantes violações de direitos da população negra realizadas pela atividade policial e pelo sistema prisional. Foi possível constatar que as atribuições constitucionais do Ministério Público, que incluem tanto a acusação penal quanto a promoção de direitos, são muitas vezes contraditórias, e dificultam a aproximação da instituição aos grupos vulneráveis, e o efetivo cumprimento das atribuições de controle externo da atividade policial e fiscalização da execução penal.

Sobre as limitações do GT-Igualdade Racial, um integrante do Grupo argumentou de forma bastante crítica, em entrevista:

Nós estamos em 2015 e o MP do maior polo brasileiro começou a discutir o racismo. Com alto índice de assassinatos de jovens negros, com várias pesquisas mostrando a discriminação e a exclusão do negro, o Ministério Público de São Paulo vem tratar disso só agora? E ainda a passos lentos e talvez com prazo fechado de validade? Estamos trilhando um caminho muito longo a passos muito curtos.

O GT-Igualdade Racial encerrou suas atividades em março de 2016. A maioria dos seus integrantes acreditava que o GT deveria ter continuidade, mas até o presente momento isso não aconteceu. A possibilidade de continuidade dos trabalhos do Grupo depende da autorização do novo Procurador Geral de Justiça, eleito em março de 2016. Trata-se de uma das dificuldades da manutenção de programas institucionais, pois, em última análise, dependem da vontade do Procurador e de disputas políticas internas. ${ }^{15}$

Por fim, cabe mencionar que um dos méritos do GT-IR foi o registro e divulgação de todas as suas atividades. Sobre o tema, os coordenadores do GT-Igualdade Racial afirmaram, em entrevista:

Não quero passar noção de desânimo, mas alguns resultados que temos vontade de instituir, não conseguimos porque o MP é uma instituição muito grande, pesada e mesmo paquidérmica. Qualquer trabalho nesse tema, para obter resultados mais concretos, seria necessário mais tempo. É muito difícil. Por isso, a intenção é deixar tudo documentado, todas as mídias dos eventos, nossa página na internet, todo conhecimento produzido está lá para a posteridade. Para os pesquisadores e gestores do futuro. Se não conseguirmos implementar nada agora, pelo menos criamos conhecimentos. Se daqui a 5 anos assumir outro grupo, ele pode aproveitar o que produzimos.

${ }_{15}$ O próprio Núcleo de Políticas Públicas, criado por um Procurador Geral de Justiça em 2012, com o objetivo de assessorar o PGJ no estabelecimento de políticas institucionais relacionadas aos direitos sociais, teve sua existência extinta ao fim do seu mandato em 2016 , mesmo sendo o novo PGJ do mesmo grupo político que o anterior. 
A partir dessa pesquisa, foi possível elencar estratégias fundamentais para o combate ao racismo e para a promoção da igualdade racial nas instituições do sistema de justiça: o registro, a coleta, análise e divulgação de casos, dados e práticas institucionais relacionadas à população negra; a inclusão do quesito raça/cor e a visibilidade do elemento racial nos formulários e cadastros internos; a criação de órgãos especializados no tema do racismo com atuação intersetorial e interdisciplinar; a implementação de ações afirmativas; a promoção de formações com o objetivo de sensibilização e mudança de comportamento dos integrantes; a utilização dos conceitos de racismo institucional e branquitude; e a participação de todos os funcionários da instituição e da sociedade civil na construção de diretrizes institucionais sobre o tema do racismo.

O Grupo Trabalho da Igualdade Racial Professor Joel Rufino dos Santos, entretanto, deu somente um primeiro passo em um longo caminho de transformações sociais necessárias e urgentes na atuação do Ministério Público de São Paulo para o enfrentamento ao racismo ainda tão presente na sociedade brasileira. Deveria tornar-se uma prática permanente e ampliada, não só no MP-SP, mas em todas as instituições do sistema de justiça.

\section{REFERÊNCIAS}

Abreu, L. E. (2013). Etnografia constitucional: Quando direito encontra a antropologia. In L. E. Abreu (Org.) Os bastidores do Supremo e outras histórias curiosas: estudos de etnografia constitucional (pp. 9-34). Brasília: UniCEUB.

Adorno, S. (1995). Discriminação racial e justiça criminal em São Paulo. Novos Estudos Cebrap, n.43, 45-63. Arantes, R. B. (1999). Direito e política: o Ministério Público e a defesa dos direitos coletivos. Rev. bras. Ci.
Soc., vol.14, n.39, 83-102.

Bento, M. A. S., Carone, I. (Org.). (2002). Psicologia Social do Racismo: estudos sobre branquitude e branqueamento no Brasil. São Paulo: Vozes.

Carneiro, S. (2000). Estratégias legais para promover a justiça social. In A. S. A. Guimarães, L. Huntley (Org.). Tirando a máscara: ensaios sobre o racismo no Brasil (pp. 311-323). São Paulo: Paz e Terra.

Crenshaw, K. (2002). Documento para o encontro de especialistas em aspectos da discriminação racial relativos ao gênero. Rev. Estudos Feministas, Florianópolis, v. 10, n.1 171-188.

Da Ros, L. (2009). Ministério Público e Sociedade Civil no Brasil Contemporâneo: em busca de um padrão de interação. Revista Política Hoje, Vol. 18, n. 1, 29-53.

Geertz, C. (1998). O saber local: fatos e leis em uma perspectiva comparativa. In C. Geertz, O saber local: novos ensaios em antropologia interpretativa (pp. 249-356). Rio de Janeiro: Vozes.

GELEDÉS, Instituto da Mulher Negra, CFEMEA, Centro Feminista de Estudos e Assessoria. (2013a). Guia de enfrentamento do racismo institucional. São Paulo: Geledés; Cfemea. Disponível em: http://www.onumuIheres.org.br/wp-content/uploads/2013/12/Guia-de-enfrentamento-ao-racismo-institucional.pdf GELEDÉS, Instituto da Mulher Negra, CFEMEA, Centro Feminista de Estudos e Assessoria, Werneck, J. (2013b). Racismo institucional: uma abordagem conceitual. São Paulo: Geledés; Cfemea. Disponível em: http://www.onumulheres.org.br/wp-content/uploads/2016/04/FINAL-WEB-Racismo-Institucional-uma-abordagem-conceitual.pdf

Guimarães, A. S. A. (2005). Racismo e Antirracismo no Brasil. São Paulo: Editora 34.

IBGE - Instituto Brasileiro de Geografia e Estatística (2010). Pesquisa Nacional por Amostra de Domicílios. Síntese dos Indicadores de 2009. Rio de Janeiro: IBGE. INFOPEN - Levantamento Nacional de informações penitenciárias (2014). DEPEN - Departamento Penitenciário Nacional - Ministério da Justiça. Disponível em: http://www.justica.gov.br/seus-direitos/politica-penal/documentos/infopen_dez14.pdf

IPEA - Instituto de Pesquisa Econômica Aplicada (2007). Boletim de Políticas Sociais: Igualdade Racial. In: IPEA. Boletim de Políticas Sociais - acompanhamento e análise, n. 14. (pp. 209-226). Disponível em: http://www.ipea.gov.br/agencia/images/stories/PDFs/ politicas_sociais/igualdaderacial74.pdf

Jaccoud, M., Mayer, R. (2008). A observação direta e a 
pesquisa qualitativa. In J. Poupart J. P. Deslauriers, L. H. Groulx, A. Laperrière, R. Mayer, A. P. Pires (Org.), A Pesquisa Qualitativa: enfoques epistemológicos e metodológicos (pp. 254-294). Petrópolis: Vozes.

Kerche, F. (1999). O Ministério Público e a Constituinte de 1987/1988. In M. T. Sadek, (Org.). O Sistema de Justiça. (pp. 106-137). São Paulo: Sumaré.

Lemgruber, J., Ribeiro, L., Musumeci, L., Duarte, T. (2016). Ministério Público: Guardião da democracia brasileira?. Rio de Janeiro: CESeC.

López, L. C. (2012). O conceito de racismo institucional: aplicações no campo da saúde. Interface - Comunic., Saúde, Educ., v. 16, n. 40, 121-34.

Macedo Jr., R. P. (2010). A evolução institucional do Ministério Público brasileiro. In Sadek, M. T. (Org.), Uma introdução ao estudo da Justiça. (pp. 65-94) Rio de Janeiro: Centro Edelstein de Pesquisas Sociais. Machado, M. R. A., Neris, N., Ferreira, C. C. (2015). Legislação Antirracista Punitiva no Brasil: uma aproximação à aplicação do direito pelos Tribunais de Justiça brasileiros. Revista de Estudos Empíricos em Direito, v. 2, 60-92.

Moraes, F. (Org.). (2013). No país do racismo institucional: dez anos de ações do GT Racismo no MPPE. Coordenação Assessoria Ministerial de Comunicação Social do MPPE, Grupo de Trabalho sobre Discriminação Racial do MPPE - GT Racismo. Recife: Procuradoria Geral de Justiça.

Moura, T. W., Custódio, R. B. (Org.). (2013). Mapa da Defensoria Pública no Brasil. Brasília: IPEA e ANADEP.

Munanga, K. (1996). As facetas de um racismo silenciado. In L. Schwarcz, R. Queiroz (Org.). Raça e Diversidade (pp. 213-229), São Paulo: Edusp.

Nielsen, L. B. (2010). The Need for Multi-Method Approaches in Empirical Legal Research. In P. Cane, H. M. Kritzer, The Oxford Handbook of Empirical Legal Research. Oxford University Press. Poupart, J. (2012). A entrevista de tipo qualitativo: considerações epistemológicas, teóricas e metodológicas. In J. Poupart J. P. Deslauriers, L. H. Groulx, A. Laperrière, R. Mayer, A. P. Pires (Org.), A Pesquisa Qualitativa: enfoques epistemológicos e metodológicos (pp. 215-252) Petrópolis: Vozes.

Proença, W. L. (2008). O método da observação participante. Rev. Antropos, Brasília, v. 2, n. 1, 8-31.

Rodriguez, J. R., Miola, I. Z., Fanti, F., Cardoso, E. L. (2013). Advocacia de interesse público no Brasil: a atuação das entidades de defesa de direitos da sociedade civil e sua interação com os órgãos de litígio do Estado. Brasília: Ministério da Justiça - Secretaria de Reforma do Judiciário.
Sadek, M. T. (Org.). (1997). O Ministério Público e a Justiça no Brasil. São Paulo: Sumaré

Sadek, M. T. (Org.). (2000). Justiça e Cidadania no Brasil. São Paulo: Sumaré.

Santos, G. A. (2015). Nem crime, nem castigo: o racismo na percepção do judiciário e das vítimas de atos de discriminação. Revista do Instituto de Estudos Brasileiros, Brasil, n. 62, 184-207.

Santos, I. A. A. (2013). Direitos humanos e as práticas de racismo. Brasília: Câmara dos Deputados, Edições Câmara.

Scheppele, K. L. (2004). Constitutional Ethnography: An Introduction. Law \& Society Review, v. 38, n. 3, 389406.

Shucman, L. V. (2014). Entre o Encardido, o Branco e - Branquíssimo: branquitude, hierarquia e poder na cidade de São Paulo. São Paulo: Anhablume.

Schritzmeyer, A. L. P. (2010). O ensino da antropologia jurídica e a pesquisa em direitos humanos. In J. R. Nalini, A. L. Carlini (Org.). Direitos Humanos e Formação Jurídica. (pp.137-153) Rio de Janeiro: Forense.

Schwarcz, L. M. (2010). Nem preto nem branco, muito pelo contrário: cor e raça na intimidade. In L. M. Schwarcz (Org.). História da Vida Privada no Brasil, v. 4 (pp. 173-244), São Paulo: Companhia das Letras.

Silva, C. A. (2001). Promotores de Justiça e novas formas de atuação em defesa de interesses sociais e coletivos. Revista Brasileira de Ciências Sociais, vol. 16, n. 45, 127-144.

Vieira, V. A., Radomysler, C. N. (2015). A Defensoria Pública e o reconhecimento das diferenças: potencialidades e desafios de suas práticas institucionais em São Paulo. Rev. Direito GV, vol.11, n.2, 455-478.

Waiselfisz, J. J. (2016). Mapa da Violência 2016. Homicídios e Juventude no Brasil. Rio de Janeiro: FLACSO. Disponivel em: http://www.mapadaviolencia.org.br/ pdf2016/Mapa2016_armas_web.pdf

Data de submissão: 09/05/2017

Data de aceite: 06/12/2019 